This manuscript was published in

Tack F.M.G., Singh S.P., Verloo M.G., 1999. Leaching behaviour of $\mathrm{Cd}, \mathrm{Cu}, \mathrm{Pb}$ and $\mathrm{Zn}$ in surface soils derived from dredged sediments. Environmental Pollution 106 (1), 107-114.

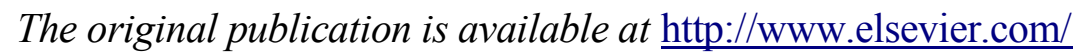

LEACHING BEHAVIOUR OF CD, CU, PB AND ZN IN SURFACE SOILS DERIVED FROM DREDGED SEDIMENTS

F. M. G. Tack ${ }^{\mathrm{a}}$, S. P. Singh ${ }^{\mathrm{b}}$ and M. G. Verloo ${ }^{\mathrm{a}}$

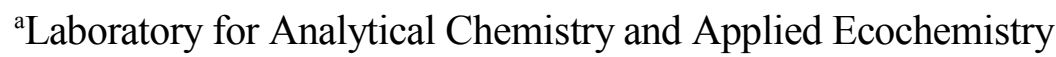

University of Ghent

Coupure Links 653

B-9000 Gent

Belgium

Tel: +3292645993

Fax: +3292646232

e-mail: Filip.Tack@rug.ac.be

${ }^{\mathrm{b}}$ University of Florida

Department of Soil and Water Sciences

Gainesville FL-32601

USA 



\title{
LEACHING BEHAVIOUR OF CD, CU, PB AND ZN IN SURFACE SOILS DERIVED FROM DREDGED SEDIMENTS
}

\author{
F. M. G. Tack ${ }^{\mathrm{a}}$, S. P. Singh ${ }^{\mathrm{b}}$ and M. G. Verloo ${ }^{\mathrm{a}}$, \\ ${ }^{a}$ Laboratory of Analytical Chemistry and Applied Ecochemistry, University of Gent, Gent, \\ Belgium. \\ ${ }^{b}$ University of Florida, Department of Soil and Water Sciences, Gainesville FL-32601, USA
}

\begin{abstract}
Leaching of heavy metals from land disposed dredged sediment spoils is a potential environmental hazard. The leaching behavior of $\mathrm{Cd}, \mathrm{Cu}, \mathrm{Pb}$ and $\mathrm{Zn}$ in surface soils sampled from abandoned dredged sediment disposal sites was assessed. Using simple mass-balance calculations, the significance of the leaching test results with respect to metal migration into underlying clean soil was appraised. The potential leachability, defined as the amounts released at constant $\mathrm{pH} 4$, decreased in the order (\% of total contents): $\mathrm{Zn}(58 \%) \approx \mathrm{Cd}(49 \%)>\mathrm{Cu}(5 \%)$ $\approx \mathrm{Pb}(2 \%)$. The kinetics of metal release were determined in a cascade shaking test using demineralized water acidified to $\mathrm{pH} 4\left(\mathrm{HNO}_{3}\right)$. Metal concentrations in the leachates were low and metal migration was, assuming uniform convective flow, predicted to be of no environmental concern. It is emphasized that any long term prediction of metal migration is uncertain.
\end{abstract}

Keywords: dredged materials, heavy metals, risk assessment, leaching, mobility

\section{INTRODUCTION}

In the Flemish region, a yearly average of $4000000 \mathrm{~m}^{3}$ (density $1600 \mathrm{~kg} \mathrm{~m}^{-3}$ ) of dredged materials must be disposed of on land (Demoen, 1989). As land-disposed dredged sediments are subjected to drying and oxidation, transformations in the chemical forms of metals may affect their mobility and plant availability (Gambrell, 1994). There is a need to assess both the short and the long term environmental impact of such disposal activities.

Possibilities for predicting long-term environmental hazards of metals are limited. Due to the complexity of the soil or sediment system and the variability of numerous influencing factors, long-term prognosis on the mobilization of metals from soils or sediments is highly uncertain (Salomons, 1995). Because of the long term involved, verification of model predictions from field observations is not possible. Despite the large uncertainties involved, predictions of metal mobility from laboratory leaching experiments allow a range of results to be obtained under plausible assumptions and thus may support decisions (Trapp \& Matthies, 1997).

Various single and sequential chemical extraction procedures provide information about the reactivity of different metal pools (Pickering, 1981). These aspects of dredged materials have been intensely studied (Förstner, 1989; Gambrell, 1994). Such tests do not allow predictions to be made about the intensity and kinetics of metal release in the field. Dynamic leaching tests, in contrast, provide insight into the dynamics of metal release under laboratory conditions. Metal release is determined as a function of increasing cumulative liquid to solid ratio (L/S ratio). The $\mathrm{L} / \mathrm{S}$ ratio may be related to a time scale for estimating heavy metal release with time in the actual field situation (Van der Sloot et al., 1984). Their greatest drawback is that long-term physicochemical changes in the soil cannot be accounted for. 
Published data on leachability of heavy metals from dredged materials as assessed by dynamic leaching tests are scarce. In a previous contribution (Tack et al., 1998), short-term leaching behavior of metal in surface soils derived from dredged materials was assessed using consecutive saturation extracts. Although metal concentrations in the saturation extracts of the oxidized soils were above levels found in pore-water of clean soils, short term metal migration was expected to be limited. However, concentrations of $\mathrm{Cd}, \mathrm{Cu}$, and $\mathrm{Zn}$ in the soil solution were elevated and may result in an enhanced availability for organisms living in these soils. In this contribution, long term leaching behavior is assessed using a cascade leaching test. Using simple mass-balance calculations, the significance of the leaching test results with respect to metal migration into underlying clean soil is evaluated.

\section{MATERIALS AND METHODS}

\section{Soil Sampling and sample preparation}

Surface soils were sampled from an uncontaminated (LG) and a relatively contaminated (MG) confined upland disposal site in the neighborhood of the city of Gent (Belgium) (Table 1). Sediments on both sites had developed into oxidized surface soil as sediment disposal had ceased for several years before our sampling. Site LG was situated in the neighborhood of Lovendegem on the right bank of the deviation canal from the river Lys. Relatively uncontaminated dredged materials were disposed 12 years before our sampling. A dense, spontaneously developed forest mainly of willow trees (Salix sp.) covered the area. Soil MG was sampled in a dredged sediment disposal site, close to Deinze-Meigem on the left bank of the same canal. The last disposal occurred three years before our sampling. The site was densely covered by stinging nettle (Urtica dioica L.). The height of sediment disposal was between 1.5 and $2 \mathrm{~m}$ on both sites.

Soil samples from 0 to $30 \mathrm{~cm}$ depth were taken from 10 random spots on an area of about 0.5 hectare by means of a $1.9 \mathrm{~cm}$ diameter hand borer and combined in polyethylene bags. The litter layer (L horizon) and the holo-organic horizon $\left(\mathrm{A}_{0}\right)$ were, when present, removed before sampling. In the laboratory, samples were thoroughly mixed and left exposed in the air to dry. After one week, the soils were hand crushed using a mortar and passed through a $2 \mathrm{~mm}$ sieve.

\section{Potential leachability test}

A test designed to assess the maximum leachable amount of metals that could become available for leaching under normal environmental conditions was applied (NEN 7341, 1994). Three g of air dried soil was suspended in $300 \mathrm{ml}$ of de-ionized water in an acid-rinsed $400 \mathrm{ml}$ glass beaker and stirred using a magnetic stirrer. Nitric acid $(1.0 \mathrm{M})$ was added through an automatic burette (Metrohm 665 dossimat) to maintain a constant $\mathrm{pH} 4$. After 4 hours, the suspensions were filtered on a paper filter (Schleicher and Schuell $589^{2}$ White Ribbon). $\mathrm{pH}$ and electrical conductivity were measured on a portion. The remaining liquid was filtered though a $0.45 \mu \mathrm{m}$ membrane filter and a few drops of concentrated nitric acid were added to decrease the sample $\mathrm{pH}$ below 2 for storage.

\section{Actual leachability}

The leaching behavior at L/S ratios from 20 to 100 was assessed using a cascade leaching test (NEN 7341, 1994). All extraction were carried out in duplicate, using acid-rinsed $125 \mathrm{ml}$ Pyrexglass centrifuge tubes provided with a screw cap. A 5 gram sample of air-dried soil was transferred to the centrifuge tube and suspended with $100 \mathrm{ml}$ of leaching reagent (de-ionized 
water acidified to $\mathrm{pH} 4$ with ultra pure $\mathrm{HNO}_{3}$ ). The suspensions were shaken continuously for 23 hours on an end-over-end mechanical shaker revolving at $30 \mathrm{rpm}$. After 15 minutes to allow settling of suspended materials, the liquid was decanted and filtered through a $0.45 \mu \mathrm{m}$ membrane filter. The membrane filter and residue were added to the sediment in the same bottle and fresh leaching reagent was added. Extractions were repeated until five fractions were collected. After determination of $\mathrm{pH}$ and electrical conductivity, collected filtrates were acidified to a $\mathrm{pH}$ below 2 with a few drops of concentrated nitric acid.

\section{Chemical analysis}

Soil $\mathrm{pH}$ was measured using a glass electrode in a 1:5 soil:water suspension after 24 hours (Cottenie et al., 1982). Organic C was determined by wet oxidation (Nelson \& Sommers, 1982). Carbonate content was determined by back-titrating an excess of $0.50 \mathrm{M} \mathrm{HCl}$ added to $1 \mathrm{~g}$ of the sample with $0.50 \mathrm{M} \mathrm{NaOH}$ (Nelson, 1982), and cation exchange capacity by saturating the sorption complex with neutral ammonium acetate (Cottenie et al., 1982). Particle size fractionation was performed by dry and wet sieving (Gee \& Bauder, 1986).

Soil metal contents were determined in the aqua regia extract. This method does not dissolve silicates or silica completely but is vigorous enough to dissolve the heavy metals not bound to silicate phases (Ure, 1990).

Immediately after filtration of extracts, $\mathrm{pH}$ and electrical conductivity were measured using a potentiometer (Orion SA 720) and a conductivity meter (LF 537, WTW, Weilheim, Germany), respectively. Metal concentrations in the extracts were determined with flame atomic absorption (Varian SpectrAA-10, Varian, Palo Alto, CA) or with graphite furnace atomic absorption (Varian SpectrAA-1475, Varian, Palo Alto, CA), using external standards, prepared from $1000 \mathrm{mg} /$ liter stock solutions of the metals (Merck).

\section{Estimation of metal migration}

To assess the environmental significance of the observed leaching test results, metal migration from the sediment layer to the underlying soil was estimated for the contaminated MG soil. The approach involving mass balances that we adopted earlier to estimate metal migration from nonferrous metal slags (Tack et al., 1993) was followed. The height of disposed dredged materials ranged between 1.5 and $2 \mathrm{~m}$. For the calculation, $1.5 \mathrm{~m}$ was assumed. The $\mathrm{L} / \mathrm{S}$ scale of the experiment was related to a time scale in the field situation as follows. One $\mathrm{m}^{2}$ of the disposal will receive 780 liter $\left(0.78 \mathrm{~m}^{3}\right)$ of precipitation yearly (average precipitation in Belgium). Of that amount, 0.2 to $0.5 \mathrm{~m}^{3} \mathrm{~m}$ year can be estimated to penetrate the soil, depending on evapotranspiration and soil permeability. Assuming a penetration rate of $0.5 \mathrm{~m}^{3} \mathrm{~m}$ year, a L/S ratio of 500/2400 or 0.21 is reached after 1 year, and it will take 4.8 years to reach an L/S ratio of 1. It is assumed that the concentration in the percolate of the dredged material disposal will change as a function of $\mathrm{L} / \mathrm{S}$ ratio in a similar way as observed in the leaching test.

The average penetration depth of the metals in underlying clean soil is estimated from a mass balance:

$$
x(\theta c+\rho s)=V c
$$

with $x$ the average penetration depth of the metals (m); $\theta$ the volumetric moisture ratio, $c$ the concentration of the metal in the leachate $\left(\mathrm{mg} \mathrm{m}^{-3}\right)$; $\rho$ the bulk density $\left(\mathrm{kg} \mathrm{m}^{-3}\right)$ of the underlying soil; $s$ the accumulated metal content in the underlying soil $(\mathrm{mg} / \mathrm{kg}) ; V$ the total volume $\left(\mathrm{m}^{3}\right)$ of percolate. 
To each L/S value there corresponds a total amount of metals, $V c$, that leached from the dredged material column. The amount of metals leached per $\mathrm{kg}$ of dredged material as a function of $\mathrm{L} / \mathrm{S}$ ratio is obtained from the leaching test results.

The relation between $s$ and $c$ is determined by the sorption characteristics of the underlying clean soil. For low metal concentrations in solution, sorption can be described by the linear relation $s=$ $K_{D} c$ which were used to calculate $s$ for a given $c$. Calculations were repeated using experimentally determined $K_{D}$ values (Table 2) for a sand loam, a loam and a clay soil. Differences in permeability between soil types were not accounted for.

\section{RESULTS}

\section{Total metal contents}

Total metal contents (Table 1) may be compared with reference values for metal contents, found in clean soils (Table 3). Total metal contents of soil LG were within the ranges for soils with a similar content of organic carbon and clay. In contrast, total contents for soil MG exceeded these ranges by a factor 5 to 10 . Sediments from the two sites originated from the same canal. Differences in total metal contents to a certain extent reflect differences in sediment pollution level at the period of dredging, but are also related to the differences in texture and organic matter content. According to the U.S.D.A. soil texture triangle, the uncontaminated soil LG is classified as a silt loam soil, while the contaminated soil MG is a silty clay soil. CEC values (Table 1) indicate a large difference in the affinity of the soils for binding metallic cations.

\section{Potential leachability}

The relative potential leachability was similar between the contaminated and the noncontaminated sediment although absolute amounts differed greatly (Table 4). On the average, the potential leachability relative to the total metal content (mean for both soils) decreased in the order: $\mathrm{Zn}(58 \%) \approx \mathrm{Cd}(49 \%)>\mathrm{Cu}(5 \%) \approx \mathrm{Pb}(2 \%)$.

\section{Actual leachability}

All leachate fractions obtained from the cascade tests had a neutral to slightly alkaline $\mathrm{pH}$, which is related to the presence of $\mathrm{CaCO}_{3}$ in the soils (Table 5). For all soils, electrical conductivities were high in the first leachates, but dropped sharply in consecutive fractions, indicating rapid leaching of soluble salts. Metal concentrations in the leachates both from the contaminated and the non-contaminated soil were in the $\mu \mathrm{g} /$ liter range (Table 6). Concentrations in the leachates from the contaminated soil were markedly higher than those from the non-contaminated soil, but remained below maximum permissible levels in water intended for human consumption (Table 7).

\section{DISCUSSION}

Leaching is a complex phenomenon in which many factors may influence the release of heavy metals from dredged sediment derived soils with time. The major geochemical factors controlling the release of metals in any leaching environment are $\mathrm{pH}$, redox potential, organic matter content, complexation, major element chemistry, liquid solid ratio (L/S ratio) and biological activity (Bourg \& Loch, 1995; Van der Sloot et al., 1996). 


\section{Potential leachability}

The potentially leachable amounts are considered to represent the fraction that can potentially become available for leaching under environmental conditions (Van der Sloot, 1991). During the test for potential leachability, carbonates are largely destroyed and associated metals released. This resulted in a high release of $\mathrm{Zn}$ and $\mathrm{Cd}$, compared to the total content, but in a minor release of $\mathrm{Cu}$ and $\mathrm{Pb}$ (Table 4). The latter elements are usually found to be less mobile. This is because at $\mathrm{pH} 4, \mathrm{~Pb}$ and $\mathrm{Cu}$ are still strongly retained by iron-oxides (Kinniburgh et al., 1976), organic matter (Brümmer, 1986; Livens, 1991) or clay minerals (Yong et al., 1990; Cavallaro \& McBride, 1984), this in contrast to Cd or Zn. On the contaminated soil MG, sequential extraction was performed according to the BCR sequential extraction scheme (Queveauviller et al., 1994). The percentages of the total amount released closely corresponded to amounts extracted in the acid extractable fraction (Singh et al., 1997).

Even in the contaminated sediment $\mathrm{MG}$, potentially leachable amounts of $\mathrm{Pb}$ and $\mathrm{Cu}$ remained lower than baseline metal levels in Flemish soils (Table 3). In a worst case situation, where all of the potentially leachable metal pool would be released, contamination of surrounding soil with these elements would still be minimal. In contrast, an actual release of the potentially leachable pool of $\mathrm{Cd}$ and $\mathrm{Zn}$ of the contaminated sediment MG would result in a significant metal transfer to the surrounding environment. Obviously, the time-scale by which release of a metal pool occurs will largely determine the severity of the environmental hazard. In assessing potential environmental effects, the time scale and dynamics of metal release need to be accounted for.

\section{Actual leachability}

In the actual leachability test, the material is subjected to accelerated leaching processes to provide insight into the dynamics of metal release. Water acidified to $\mathrm{pH} 4$ is suggested as a standard leaching agent that simulates the most significant effects of acid rain (Van der Sloot, 1991).

The metal contents in the leachates remained essentially constant throughout the leaching experiment (Table 6). Higher concentrations were observed in the first fractions only for $\mathrm{Zn}$, indicating rapid leaching of a readily soluble fraction. The concentration levels in the cascade leaching test suggests that, provided no major physicochemical changes occur in the dredged material, release of metals in the field can be expected to occur slowly, but steadily.

Metal concentrations in the leachates both from the contaminated and the non-contaminated soil were in the $\mu \mathrm{g} /$ liter range. Concentrations in the leachates from the contaminated soil were significantly higher than these from the non-contaminated soil, but remained below maximum permissible levels in water intended for human consumption (Table 7).

Although the potential leachability test revealed the presence of a large mobile pool of $\mathrm{Cd}$ and $\mathrm{Zn}$ in the contaminated sediment, the actual leachability of these elements was very low, below $20 \%$ of the potentially extractable metal pool. This is caused by the high amount of carbonates that effectively buffered any acidity present in the leachate.

\section{Metal migration in the underlying soil}

Results of a leaching test can be understood in terms of potential environmental effects only when they are applied to field situations. Under Belgian weather conditions, the L/S scale of the experiment may be estimated to correspond to between 500 and 1000 years in a field situation where the dredged materials are disposed at a height of $1.5 \mathrm{~m}$ (see "Materials and Methods"). Using mass-balance calculations and assuming uniform convective flow, the average migration 
depth of leached metals in underlying clean soil as a function of time may be estimated from the leaching test results.

Examples of such predicted migration results are given for $\mathrm{Cd}$ and $\mathrm{Pb}$ (Figures 1 and 2). The total element load that is predicted to leach from the sediment after a given $\mathrm{L} / \mathrm{S}$ ratio, which corresponds to a time period in the field situation, will be accumulated in the underlying soil over a certain depth. The average penetration depth approach is useful to get a first approximation of the extent of metal migration and accumulation that can result from an observed leaching behavior. In order to calculate realistic migration profiles, more complex modeling is needed that accounts for phenomena like diffusion and hydrodynamic dispersion (Tack et al., 1993).

Soil sorption characteristics are of extreme importance in determining the rate of metal movement. In the sandy soil, Cd is predicted to accumulate up to $0.2 \mathrm{mg} \mathrm{kg}$ over a depth of 50 $\mathrm{cm}$. In a clay soil, the same amount of metals would be retained in only $5 \mathrm{~cm}$ of clay soil, but accumulate up to $2 \mathrm{mg} / \mathrm{kg}$ (Figure 1).

When considering absolute amounts of $\mathrm{Cd}$, migration is not of a great concern. In the sandy soil, metal accumulation is predicted to be less than $0.2 \mathrm{mg} / \mathrm{kg}$, an amount which is within ranges normally found in unpolluted soils worldwide (0.07-1.1) (Kabata-Pendias \& Pendias, 1984). Metal migration is predicted to extend to more than two meters. It is therefore likely that there will be $\mathrm{Cd}$ transfer to the groundwater in the long term. According to the leaching test results, metal concentrations in the leachate in the long term would be on the order of $0.5 \mu \mathrm{g}$ liter, which is lower than concentrations that are considered safe for drinking water $(5 \mu \mathrm{g}$ liter Smeets \& Amavis, 1981).

$\mathrm{Pb}$ and $\mathrm{Cu}$ generally are less mobile elements in soils. This is also reflected in the estimations of metal migration for $\mathrm{Pb}$. In the sand soil, $\mathrm{Pb}$ is predicted to be retained at $20 \mathrm{~cm}$ at the long term, while practically no migration is predicted for the clay soil.

With respect to the environmental significance of the predicted metal migration, conclusions are similar for all elements. Although long term effects are predicted to be of no concern, previous experiments involving consecutive saturation extractions on the contaminated sediment (Tack et al., 1998) suggested that pore water concentrations in the short term would be elevated and could give rise to an enhanced availability for organisms living in these soils.

Acidification of the soil is a potential long-term effect that may seriously alter the mobility of metals. In the leaching test at L/S 100 , a total amount of $0.1 \mathrm{~mol}$ of $\mathrm{H}^{+}$was added to $1 \mathrm{~kg}$ of dry sediment. A carbonate content of $8 \%$ (soil MG) corresponds to $0.8 \mathrm{~mol}^{\mathrm{m}} \mathrm{CaCO}_{3}$ per $\mathrm{kg}$ of dry soil, or to a buffering capacity of $1.6 \mathrm{~mol} \mathrm{H}^{+}$per $\mathrm{kg}$ of dry soil. Thus, an amount of acidity equivalent to 500 years of acidic rain neutralized $6 \%$ of the total buffering capacity of the soil. The soil would thus be capable to adequately buffer any input through acidic rain for a long time.

The approach presented allows assessment of potential metal migration in the field from leachability data. Several factors limit the accuracy of such predictions. First, soils or sediments are complex systems with biological activity, and laboratory experiments cannot account for changes in physico-chemical properties that may occur in the long term. Phenomena of diffusion and hydrodynamic dispersion will lead to a greater migration depth and a lower accumulation than that predicted from the mass-balance calculations. To an important extent, preferential flow, eventually in combination with organic complexation, can accelerate metal leaching through soils much above the extent expected from the binding capacity of soils (Camobreco et al., 1996). Metals moving in preferential flow paths as non-adsorptive metal/organic complexes may also exhibit a low potential for interaction and adsorption in the subsoil, thus facilitating mobility. The lack of significant metal deposition in the subsoil may thus not be reliable evidence of immobility (Camobreco et al., 1996; Richards et al., 1998). 
Differences in soil permeability also were not accounted for. Predicted migration for clay soils that can be highly impermeable for water, could therefore tend to be overestimated. The approach presented nevertheless sheds more light on the dynamics and kinetics of metal release from a metal contaminated site. It provides a basis from which a realistic and differentiated view on the potential risks of a disposal site may be obtained.

\section{References}

Bourg, A. C. M. \& Loch, J. P. G. (1995). Mobilisation of heavy metals as affected by pH and redox conditions. In Biogeodynamics of pollutants in soils and sediments, ed. W. Salomons \& W. M. Stigliani, Springer Verlag, New York, pp. 87-102.

Brümmer, G.W. (1986). Heavy metal species, mobility and availability in soils. In The importance of chemical "speciation" in chemical processes, ed. M. Bernhard, F.E. Brinckman, P.J. Sadler, Springer-Verlag, New York, pp. 169-92.

Camobreco,V.J., Richards, B.K., Steenhuis, T.S., Peverly, J.H. \& McBride, M.B. (1996). Movement of heavy metals through undisturbed and homogenized soil columns. Soil Sci., 161, 740-50.

Cavallaro, N. \& McBride, M.B. (1984). Zinc and copper sorption and fixation by an acid soil clay: effect of selective dissolutions. Soil Sci. Soc. Am. J., 48, 1050-54.

Cottenie, A., Verloo, M., Kiekens, L., Velghe, G. \& Camerlynck, R. (1982). Chemical analysis of plants and soils. IWONL, Brussels.

Demoen, J. (1989). Naar een nieuwe aanpak van de berging van onderhoudsbaggerspecie van de bevaarbare waterlopen. Water 47, 117-20.

Förstner, U. (1989). Contaminated sediments. Springer-Verlag, Berlin.

Gambrell, R.P. (1994). Trace and toxic metals in wetlands - a review. J. Environ. Qual. 23, 88391.

Gee, G.W. \& Bauder, J.W. (1986). Particle-size analysis. In Methods of soil analysis, Part 1. Physical and mineralogical methods, Agronomy series 9 (2nd edition), ed. Klute, A. American Society of Agronomy, Madison, WI, pp. 377-82.

Kabata-Pendias, A. \& Pendias, H. (1984). Trace elements in soils and plants. CRC Press, Boca Raton, Florida.

Kiekens, L. (1980). Adsorptieverschijnselen van zware metalen in gronden. Doctoraatsthesis. RUG, Gent.

Kinniburgh, D.G., Jackson, M.L. and Syers, J.K. (1976). Adsorption of alkaline earth, transition, and heavy metal cations by hydrous oxide gels of iron and aluminum. Soil Sci. Soc. Am. J. 40, 796-99.

Livens, F.R. (1991). Chemical reactions of metals with humic material, Environ. Pollut. 70, 183208. 
Nelson, D.W. \& Sommers, L.E. (1982). Total carbon, organic carbon, and organic matter. In Methods of soil analysis, Part 2. Chemical and microbiological properties, Agronomy series 9 (2nd edition), ed. A. L. Page, R. H. Miller \& D. R. Keeney, D.R. American Society of Agronomy, Madison, Wisconsin, pp. 539-79.

Nelson, R.E. (1982). Carbonate and gypsum. In Methods of soil analysis, Part 2. Chemical and microbiological properties, Agronomy series 9 (2nd edition), ed. A. L. Page, R. H. Miller \& D. R. Keeney, D.R. American Society of Agronomy, Madison, Wisconsin, pp. 181-97.

NEN 7341 (1994). Determination of availability for leaching of inorganic components from granular (wastes) material, Final version, July 1994, Netherlands Energy Research Foundation, Petten, The Netherlands.

Pickering, W.F. (1981). Selective chemical extraction of soil components and bound metal species. Crit. Rev. Anal. Chem., 12, 233-66.

Quevauviller, P., Rauret, G., Muntau, H., Ure, A.M., Rubio, R., López-Sánchez, J.F., Fiedler, H.D. \& Griepink, B. (1994). Evaluation of a sequential extraction procedure for the determination of extractable trace metal contents in sediments. Fresenius J. Anal. Chem., 349, 808-14.

Richards, B.K., Steenhuis, T.S., Peverly, J.H., McBride, M.B. (1997). Metal mobility at an old, heavily loaded sludge application site. Environ. Pollut., 99, 365-377.

Salomons, W. (1995). Long-term strategies for handling contaminated sites and large-scale areas. In Biogeodynamics of pollutants in soils and sediments: risk assesment of delayed and non-linear responses, ed. W. Salomons \& W. M. Stigliani, Springer-Verlag, Berlin, pp. $1-30$.

Singh, S.P., Tack, F.M.G. \& Verloo, M. (1998). Heavy metal fractionation and extractability in dredged sediment derived surface soils. Water Air Soil Pollut., 102, 313-28.

Smeets, J. \& Amavis, R. (1981). European community directive relating to the quality of water intended for human consumption. Water Air Soil Pollut. 15, 483-502.

Tack, F.M.G., Verloo, M.G., Vanmechelen, L. \& Van Ranst, E. (1997). Baseline concentration levels of trace elements as a function of clay and organic carbon contents in soils in Flanders (Belgium). Sci. Tot. Environ. 201, 113-123.

Tack, F.M.G., Masscheleyn, P.H. \& Verloo, M.G. (1993). Leaching behaviour of granulated non-ferrous metal slags. In Environmental contamination, ed. J. P. Vernet. Elsevier, Amsterdam, pp. 103-17.

Tack, F.M.G., Singh, S.P. \& Verloo, M.G. (1998). Heavy metal concentrations in consecutive saturation extracts of dredged sediment derived surface soils. Environ. Pollut., 103, 109115.

Trapp, S., Matthies, M. (1998). Chemodynamics and environmental modeling: an introduction. Springer-Verlag, Berlin.

Ure, A.M. (1990). Methods of analysis for heavy metals in soils. In Heavy metals in soils, ed. B. J. Alloway. Blackie and Son, Glasgow, pp. 40-73. 
Van der Sloot, H.A., Piepers, O. \& Kok, A. (1984). A standard leaching test for combustion residues. Shell BEOP-31. Studiegroep Ontwikkeling Standaard Uitloogtesten Verbrandingsresiduen, Petten, The Netherlands.

Van der Sloot, H.A., Comans, R.N.J. and Hjelmer, O. (1996). Similarities in the leaching behaviour of trace contaminants from waste, stabilised waste, construction materials and soils, Sci. Total Environ., 178, 111-126.

Van der Sloot, H.A., (1991), Systematic leaching behaviour of trace elements from construction materials and waste materials, Tech. Report ECN RX 91-088, Netherlands Energy Research Foundation, Petten, The Netherlands.

Yong, R.N., Warkentin, B.P., Phadungchewit, Y. \& Galvez, R. (1990). Buffer capacity and lead retention in some clay materials. Wat. Air Soil Pollut., 53, 53-67. 
Table 1. Physical and chemical characteristics of the dredged sediment derived surface soils (mean \pm standard deviation of three replicates)

\begin{tabular}{|c|c|c|}
\hline & Soil LG & Soil MG \\
\hline Years since disposal & 12 years & 3 years \\
\hline $\mathrm{pH}-\mathrm{H}_{2} \mathrm{O}$ & 8.2 & 7.2 \\
\hline Organic carbon ( $\%)$ & 0.5 & 5.5 \\
\hline $\mathrm{CaCO}_{3}(\%)$ & 10.0 & 7.8 \\
\hline $\mathrm{CEC}(\mathrm{cmol} / \mathrm{kg})$ & 6.6 & 29.7 \\
\hline \multicolumn{3}{|c|}{ Granulometric analysis ( $\%$ of $0-2 \mathrm{~mm}$ fraction) } \\
\hline $0-2 \mu \mathrm{m}$ & 9 & 47 \\
\hline $2-50 \mu \mathrm{m}$ & 53 & 51 \\
\hline $50 \mu \mathrm{m}-2 \mathrm{~mm}$ & 38 & 2 \\
\hline \multicolumn{3}{|c|}{ Total metal contents ( $\mathrm{mg} / \mathrm{kg}$ of dry matter) } \\
\hline $\mathrm{Cd}$ & $1.3 \pm 0.4$ & $17 \pm 2$ \\
\hline $\mathrm{Cu}$ & $7.7 \pm 0.1$ & $210 \pm 21$ \\
\hline $\mathrm{Pb}$ & $14 \pm 2$ & $274 \pm 14$ \\
\hline $\mathrm{Zn}$ & $38 \pm 12$ & $1450 \pm 90$ \\
\hline
\end{tabular}


Table 2. Metal distribution coefficients $K_{D}$ for three soils (Kiekens, 1986)

\begin{tabular}{llll}
\hline & sand loam & loam & clay \\
\hline $\mathrm{Cd}$ & 57 & 540 & 465 \\
$\mathrm{Cu}$ & 818 & 1096 & 10000 \\
$\mathrm{~Pb}$ & 705 & 2039 & 12811 \\
$\mathrm{Zn}$ & 26 & 107 & 1250 \\
\hline
\end{tabular}


Table 3. Baseline metal concentrations ( $\mathrm{mg} / \mathrm{kg}$ dry soil) in Flanders, Belgium, as a function of clay and organic carbon content of the soil (Tack et al., 1997)

\begin{tabular}{|c|c|c|c|c|c|c|}
\hline \multirow{3}{*}{$\begin{array}{l}\text { Clay (\%) } \\
\text { OC }(\%)\end{array}$} & \multicolumn{6}{|c|}{$90 \%$ upper confidence limit of the observation } \\
\hline & \multicolumn{2}{|r|}{5} & \multicolumn{2}{|c|}{15} & \multicolumn{2}{|c|}{25} \\
\hline & 1 & 3 & 1 & 3 & 1 & 3 \\
\hline $\mathrm{Cd}$ & 0.6 & 1.0 & 1.1 & 1.5 & 1.5 & 2.0 \\
\hline $\mathrm{Cu}$ & 17 & 21 & 21 & 26 & 23 & 29 \\
\hline $\mathrm{Pb}$ & 38 & 51 & 47 & 60 & 53 & 68 \\
\hline $\mathrm{Zn}$ & 56 & 70 & 72 & 88 & 84 & 101 \\
\hline
\end{tabular}


Table 3. Potentially leachable metal contents $(\mathrm{mg} / \mathrm{kg}$ dry matter and \% of the total content; mean \pm standard deviation of three replicates)

\begin{tabular}{|c|c|c|c|c|}
\hline \multirow[t]{3}{*}{ Metal } & \multicolumn{2}{|c|}{$\mathrm{LG}$} & \multicolumn{2}{|c|}{$\mathrm{MG}$} \\
\hline & $\begin{array}{c}\text { Cumulative mass } \\
\text { leached }\end{array}$ & $\begin{array}{c}\% \text { of total content } \\
\text { leached }\end{array}$ & $\begin{array}{c}\text { Cumulative mass } \\
\text { leached }\end{array}$ & $\begin{array}{c}\% \text { of total content } \\
\text { leached }\end{array}$ \\
\hline & $(\mathrm{mg} / \mathrm{kg})$ & $(\%)$ & $(\mathrm{mg} / \mathrm{kg})$ & $(\%)$ \\
\hline $\mathrm{Cd}$ & $0.7 \pm 0.1$ & $53 \%$ & $7.5 \pm 0.2$ & $44 \%$ \\
\hline $\mathrm{Cu}$ & $2.3 \pm 0.10$ & $30 \%$ & $16.4 \pm 3.7$ & $7.8 \%$ \\
\hline $\mathrm{Pb}$ & $0.6 \pm 0.1$ & $4.2 \%$ & $6.3 \pm 1.9$ & $2.3 \%$ \\
\hline $\mathrm{Zn}$ & $18.2 \pm 0.7$ & $48 \%$ & $713 \pm 2$ & $49 \%$ \\
\hline
\end{tabular}


Table 4. $\mathrm{pH}$ and electrical conductivity in the fractions of the leaching tests (mean \pm standard deviation of three replicates)

\begin{tabular}{cccccc}
\hline Fraction & 1 & 2 & 3 & 4 & 5 \\
L/S Ratio & 20 & 40 & 60 & 80 & 100 \\
\hline \multicolumn{7}{c}{$\mathrm{pH}$} \\
LG & $7.87 \pm 0.00$ & $7.93 \pm 0.01$ & $7.88 \pm 0.06$ & $7.83 \pm 0.06$ & $7.96 \pm 0.06$ \\
MG & $7.28 \pm 0.03$ & $7.72 \pm 0.11$ & $7.92 \pm 0.14$ & $7.91 \pm 0.20$ & $8.05 \pm 0.07$ \\
\multicolumn{7}{c}{ Electrical conductivity $(\mu \mathrm{S} / \mathrm{cm})$} \\
LG & $202 \pm 7$ & $93 \pm 2$ & $87 \pm 3$ & $87 \pm 3$ & $89 \pm 0$ \\
MG & $1026 \pm 24$ & $214 \pm 6$ & $128 \pm 5$ & $118 \pm 9$ & $102 \pm 5$ \\
\hline
\end{tabular}


Table 5 Trace metal concentrations ( $\mu \mathrm{g} /$ liter) in the fractions of the cascade shaking test (mean \pm standard deviation of three replicates)

\begin{tabular}{|c|c|c|c|c|c|c|c|}
\hline \multirow{3}{*}{$\begin{array}{l}\text { Fraction } \\
\text { L/S Ratio }\end{array}$} & \multicolumn{5}{|c|}{$\begin{array}{l}\text { Leaching } \\
(\mu \mathrm{g} / \text { liter })\end{array}$} & \multirow{3}{*}{$\begin{array}{l}\text { Cumul. } \\
\text { mass } \\
\text { leached } \\
(\mathrm{mg} / \mathrm{kg})\end{array}$} & \multirow{3}{*}{$\begin{array}{c}\% \text { of total } \\
\text { content } \\
\text { leached } \\
(\%)\end{array}$} \\
\hline & 1 & 2 & 3 & 4 & 5 & & \\
\hline & 20 & 40 & 60 & 80 & 100 & & \\
\hline & \multicolumn{7}{|c|}{ Soil LG } \\
\hline $\mathrm{Cd}$ & $0.5 \pm 0.3$ & $0.1 \pm 0.1$ & $0.1 \pm 0.0$ & $0.2 \pm 0.2$ & $0.2 \pm 0.1$ & 0.02 & $1.7 \%$ \\
\hline $\mathrm{Cu}$ & $9 \pm 0.4$ & $5 \pm 1$ & $4 \pm 1.5$ & $3 \pm 0.0$ & $4 \pm 0.2$ & 0.50 & $6.5 \%$ \\
\hline $\mathrm{Pb}$ & $0.7 \pm 0.1$ & $0.2 \pm 0.1$ & $0.4 \pm 0.3$ & $0.2 \pm 0.1$ & $0.2 \pm 0.1$ & 0.03 & $0.2 \%$ \\
\hline $\mathrm{Zn}$ & $49 \pm 3$ & $13 \pm 2$ & $13 \pm 1$ & $12 \pm 3$ & $15 \pm 3$ & 2.0 & $5.4 \%$ \\
\hline \multicolumn{8}{|c|}{ Soil MG } \\
\hline $\mathrm{Cd}$ & $3.3 \pm 0.4$ & $0.7 \pm 0.2$ & $0.5 \pm 0.1$ & $0.6 \pm 0.2$ & $0.6 \pm 0.2$ & 0.11 & $0.7 \%$ \\
\hline $\mathrm{Cu}$ & $39 \pm 3$ & $37 \pm 3$ & $22 \pm 4$ & $20 \pm 3$ & $13 \pm 1$ & 2.6 & $1.2 \%$ \\
\hline $\mathrm{Pb}$ & $0.6 \pm 0.2$ & $1.1 \pm 0.7$ & $1.2 \pm 0.9$ & $2.4 \pm 0.6$ & $1.2 \pm 1.7$ & 0.13 & $0.0 \%$ \\
\hline $\mathrm{Zn}$ & $129 \pm 10$ & $33 \pm 6$ & $29 \pm 9$ & $27 \pm 7$ & $38 \pm 10$ & 5.1 & $0.4 \%$ \\
\hline
\end{tabular}


Table 6 Guide levels (GL) and maximum admissible concentrations (MAC) ( $\mu \mathrm{g} /$ liter) as defined in the European Communities Directive relating to the quality of water intended for human consumption (Smeets \& Amavis, 1981)

\begin{tabular}{lll}
\hline Parameter & Guide Level (GL) & $\begin{array}{l}\text { Maximum Admissible } \\
\text { Concentration (MAC) }\end{array}$ \\
\hline $\mathrm{Cd}$ & 5 \\
$\mathrm{Cu}$ & 100 & \\
$\mathrm{~Pb}$ & & 50 \\
$\mathrm{Zn}$ & 100 & \\
\hline
\end{tabular}




\section{List of figures}

Fig. 1. Accumulation and migration depth of $\mathrm{Cd}$, predicted for underlying soils with different metal sorption characteristics

Fig. 2. Accumulation and migration depth of $\mathrm{Pb}$, predicted for underlying soils with different metal sorption characteristics 

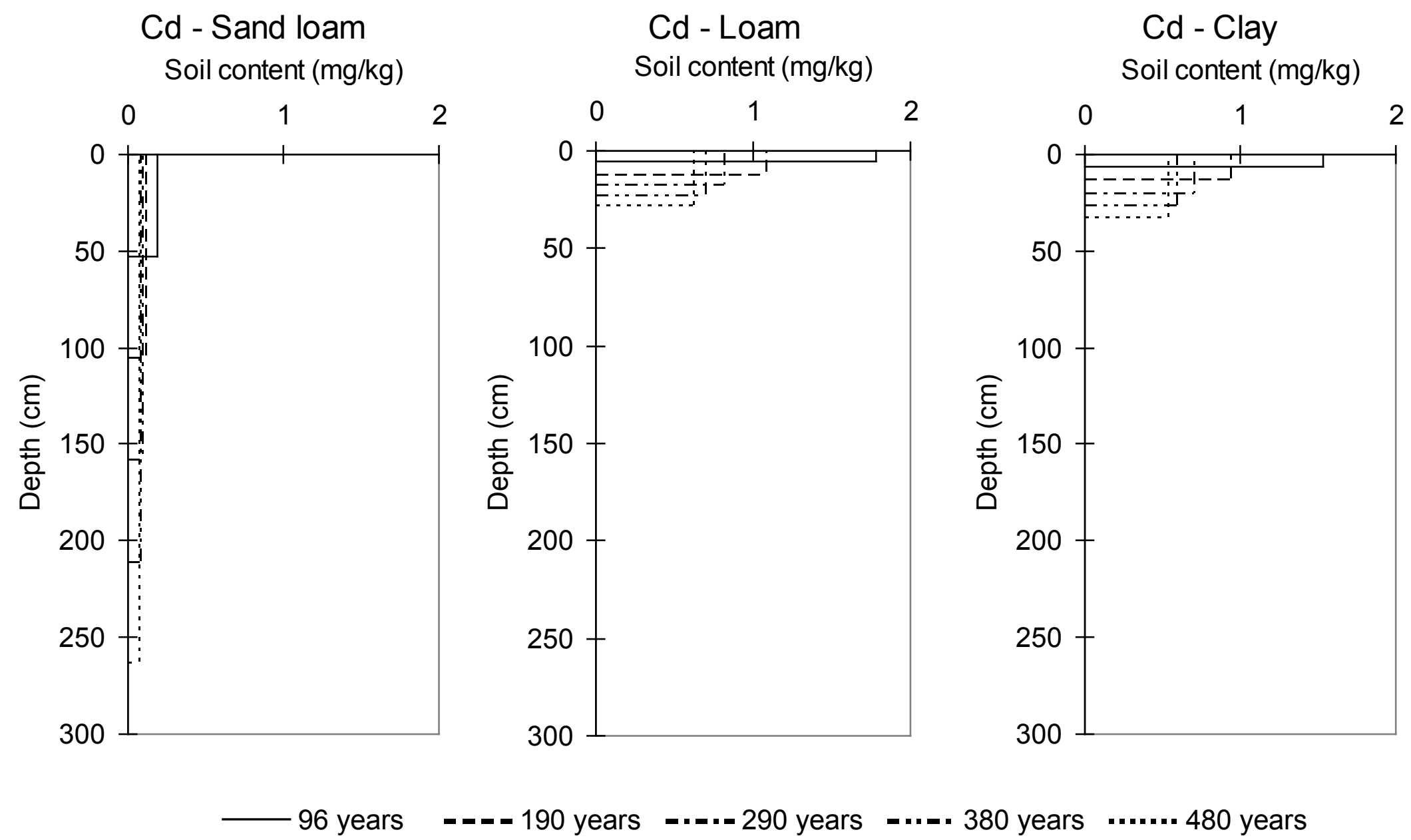

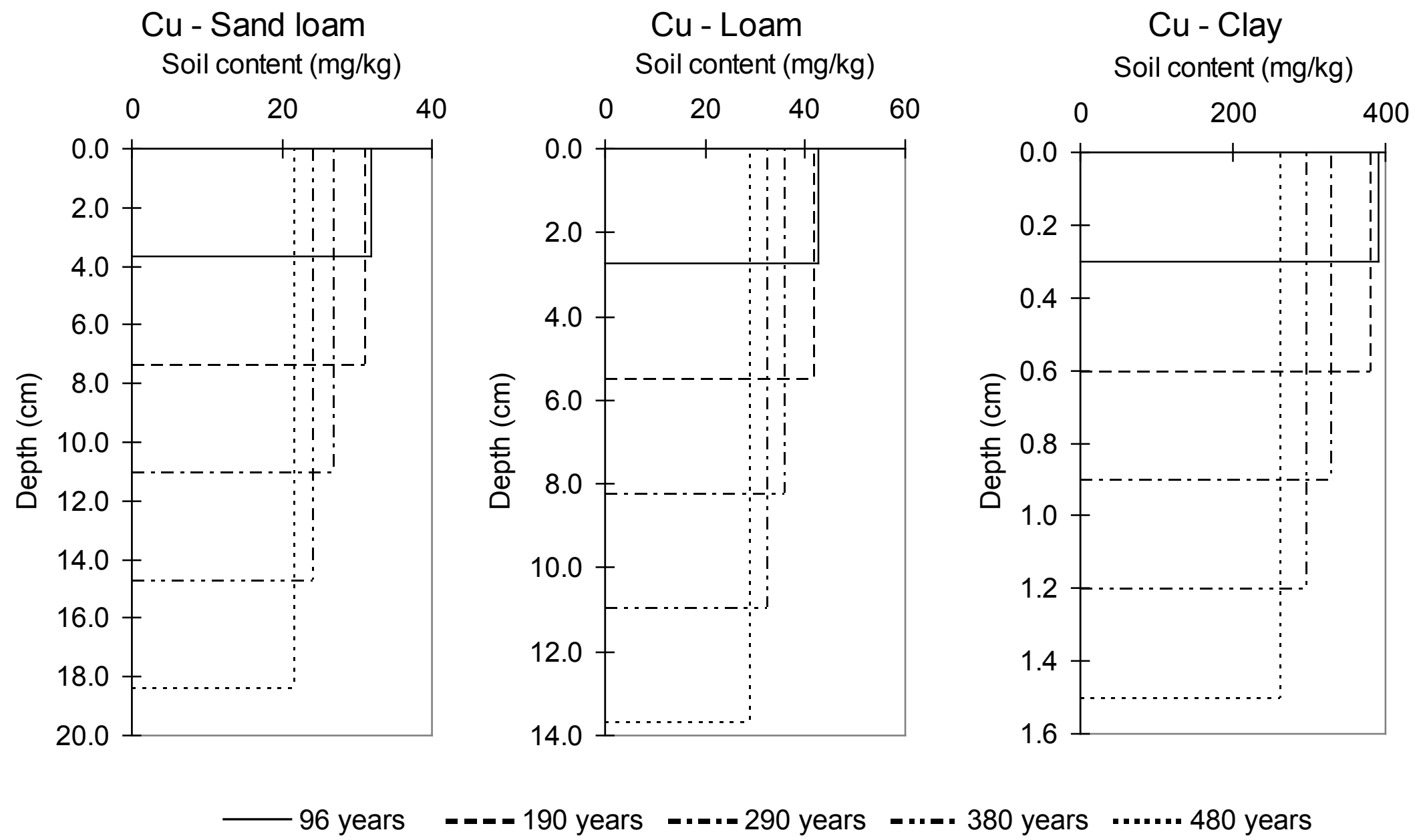

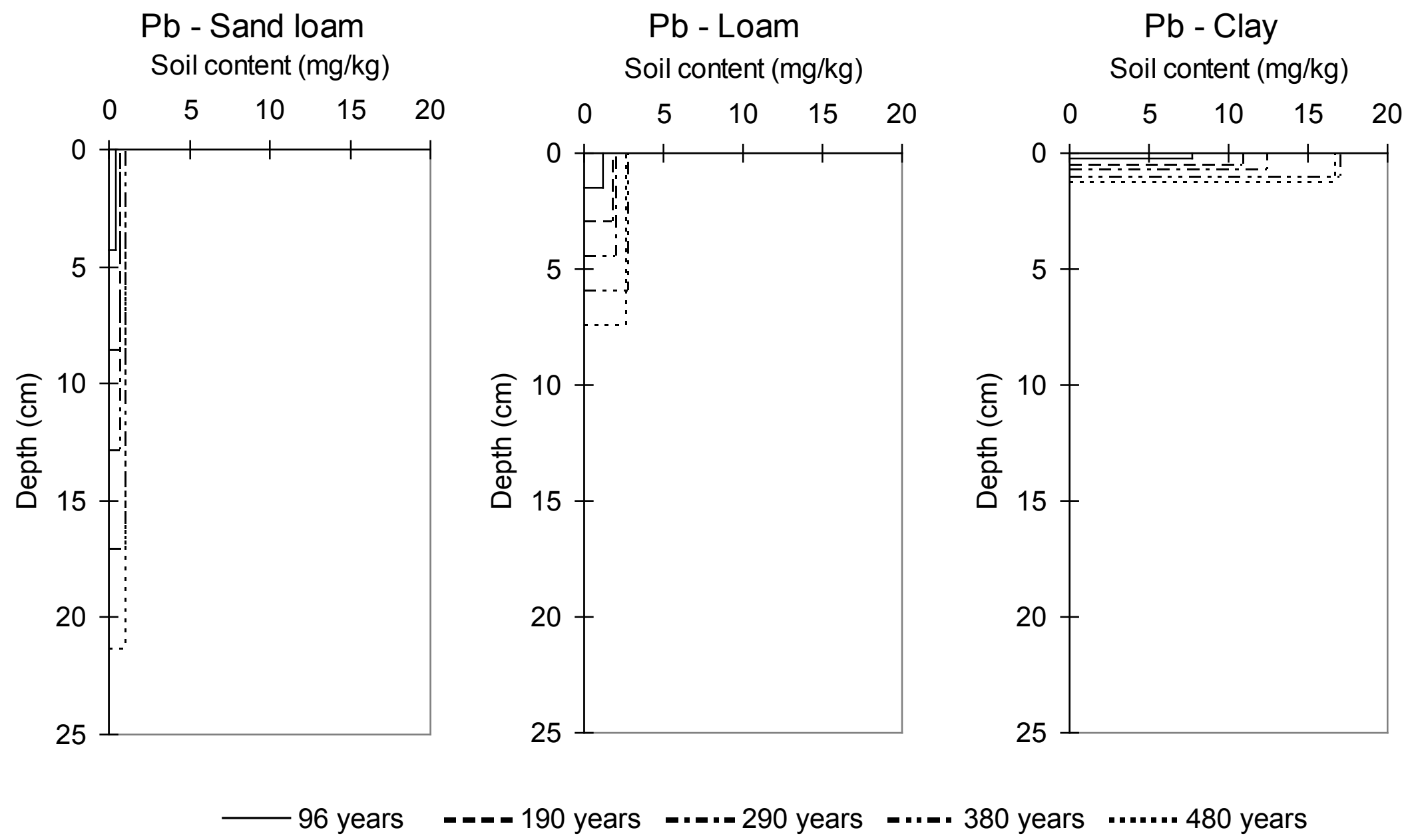

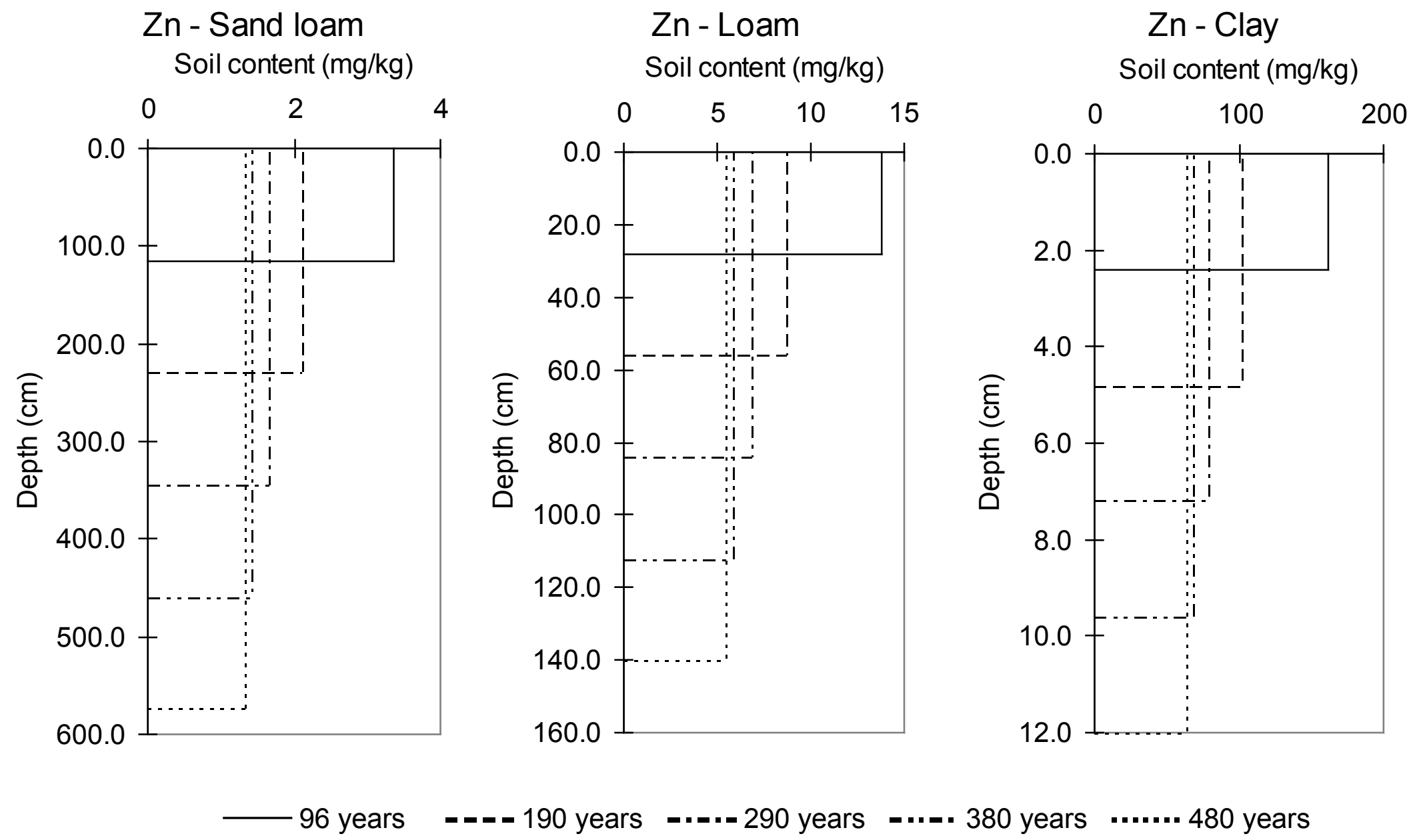